\title{
A Case Report on Grade II Oligodendroglioma by Ayurvedic Intervention
}

\author{
Sundara Raman ${ }^{1}$, B. N. Ashwini² and K. Sivabalaji2 ${ }^{*}$ \\ ${ }^{1}$ Nilgiris Ayurvedic Treatment Centre Pvt. Ltd., Hulical, Coonoor - 643234, Tamil Nadu, India; \\ omsundarayur@yahoo.co.in \\ 2Department of Shalakya Tantra, Amrita School of Ayurveda, Amrita Deemed University, Kollam - 690525, \\ Kerala, India; drashwinibelludi@gmail.com, balajisiva85k@gmail.com
}

\begin{abstract}
(1) Rationale for this case report: The current treatment modality for oligodendroglioma is surgical intervention and radiation treatment. This case report shows the effective management with Ayurvedic treatment of a case diagnosed as Grade II oligodendroglioma which was posted for resection and chemotherapy. The MRI results after treatment clearly suggest the significant reduction of the Grade II oligodendroglioma. (2) Presenting concerns: A 26-year young lady who was diagnosed with the Grade II oligodendroglioma was admitted in the hospital. She was posted for the excision, resection, chemotherapy and radiotherapy. The features were suggestive of Grade II oligodendroglioma has been diagnostic by MRI. (3) Interventions: Panchakarma procedures including the snehana, svedana, virechana, nasya and kayaseka was started along with internal medications and surgery was deferred because the patient responded positively. (4) Outcomes: The outcome of this case study reveals that there was significant reduction of the Grade II oligodendroglioma. (5) Main lesson(s) from this case report: Non-surgical intervention of Grade II oligodendroglioma demonstrating the reduction. Multiple clinical trials should be conducted to establish this treatment as general treatment for the oligodendroglioma.
\end{abstract}

Keywords: Alternative Therapy, MRI, Tumour

\section{Introduction}

Oligodendrogliomas (from the Greek 'oligo' meaning "few" and 'dendro' meaning "trees") are diffusely infiltrating, usually differentiated gliomas composed of cells that morphologically resemble oligodendroglial cells. They occur primarily in adults (9.4\% of all primary brain and CNS tumours), with the average age at diagnosis being 35. Microscopically, they are composed of cells with small to slightly enlarged nuclei and a small amount of eosinophilic cytoplasm. They are often referred to as "fried egg" cells based on their histological appearance. They appear as a monotonous population of mildly enlarged round cells that infiltrate normal brain parenchyma. The exact cause is unknown ${ }^{1}$; however, some studies link oligodendrogliomas with viral causes. Occasional clustering occurs in some families, although the mode of inheritance is not established. Diagnoses of oligodendrogliomas are confirmed using Computerized Tomography (CT), Magnetic Resonance Imaging (MRI), and Current management options include surgical resection, radiotherapy, and chemotherapy. Oligodendrogliomas may be correlated with and grouped under the Arbuda spectrum of conditions according to Āyurveda. ĀcâryaSuśruta explains that the aggravated Dosās vitiate Māmsa and produce large, deep-rooted, slowly developing, non-suppurative, and swollen fleshy masses in the affected parts of the body. These are collectively termed as Arbuda. Management of Arbuda revolves around Sodhana, Lepa, and internal medications. Repeated Svedana (sudation) should be done and the mass should be squeezed many times. If the condition does not improve by these methods, then Chedana (excision) of the Arbuda should be done.

*Author for correspondence 


\section{Case Report}

A 26-year-old, well-built, non-diabetic, non-hypertensive female presented with a 2-year history of confusion and difficulty in language comprehension associated with numbness and tingling in both arms and a feeling of rejection and anger in life. The patient experienced a sudden non-comprehension of letters and inability to use dining utensils 2 years ago, along with seizure episodes, she consulted a doctor, who diagnosed her case as a grade II oligodendroglioma and advised radiotherapy for three weeks. This showed no progress as the neoplasm continued to steadily grow. Excision of the mass by a left temporo-parietal craniotomy was done in January 2017.

In 2004, she was diagnosed with Grave's disease, and then hypothyroidism. In 2014, she developed depression, which was due to the death of her father. In 2015, she consulted for cannabis dependence. In the summer of 2016, she took a trip to Costa Rica, where she developed fever and malaise. By August 12 ${ }^{\text {th }}, 2016$, she developed confusion, fever, and headache. At this time, an MRI scan revealed a left temporal lesion interpreted as encephalitis, for which she underwent treatment. On return to Netherlands on September $9^{\text {th }}$, her confused state increased and, on September $14^{\text {th }}$, she was found to have acute psychosis. She does not report any allergies or habits, follows a mixed diet, and her sleep is sound. Bowel, appetite, and micturition are normal and sleep is sound. Neurological examination on admission revealed no abnormalities.

\section{Clinical Findings}

MRI scanning done on July $1^{\text {st }}, 2017$ revealed:

- A post-operative cystic encephalomalacia/proencephalic cyst measuring $5.2 \mathrm{~cm}$ antero-posteriorly $\mathrm{x}$ $2.6 \mathrm{~cm}$ (TR), $x 2.6 \mathrm{~cm}$ (CC) in the left inferior temporal gyrus without any mass effects.

- Left temporo-parietal craniotomy changes.

Examinations of cranial nerves were normal, with normal gait and normal sensibility of the face. These findings suggested the diagnosis of oligodendroglioma.

\section{Management}

The patient was admitted on July $10^{\text {th }}, 2017$. Internal medicines such as Kāñcanāra Guggulu, Gudūcì Sattva, Septillin tablets, and Aśvagandha capsules were started on admission and continued till discharge. Sarvānga Abhyanga with Kottamcukkädi Taila ${ }^{2}$ and Dhänvantara Taila ${ }^{3}$ followed by Cürna Pinda Sveda with Kottamcukkādi Cūrna was done for 3 days. Snehapāna with Pañcatiktaka Guggulu Ghrta ${ }^{4}$ followed by Nādì Sveda with Eranda
Patrawas administered for 4 days, after which Virecana was induced by Avipattikara Yoga ${ }^{5}$. Nasya was done for 7 days with 4 drops of Anutaila ${ }^{6}$ mixed with 8 drops of Ksirabala Taila. Abhyanga and Sirodhāra with 75\% Brāhmi Taila and 25\% Kottamcukkādi Taila was done for 7 days. Pizhiccil with Dhānvantara Taila, Kottamcukkādi Taila, and Pinda Taila ${ }^{7}$, and Cūrna Pinda Sveda with Kottamcukkādi Cūrna was done for 3 days.

\section{Discussion}

The exact aetiology of oligodendroma is unknown. They appear as a monotonous population of mildly enlarged round cells that infiltrate normal brain parenchyma. Microscopically, they are composed of cells with small to slightly enlarged nuclei and a small amount of eosinophilic cytoplasm. They are often referred to as "fried egg" cells based on their histological appearance. ĀcāryaSuśruta explains that the aggravated Dosās vitiate Màmsa and produce large, deep-rooted, slowly developing, nonsuppurative, and swollen fleshy masses in the affected parts of the body. These are collectively termed as Arbuda which can be correlated to oligodendroglioma ${ }^{8}$. Treatment principle involves Śodhana, Lepa, and internal medications and repeated Svedana (sudation) should be done and the mass should be squeezed many times. Kanchanaraguggulu, guduchisatva, septilin and asvaganda capsule was started as the internal medications (Tables 1 , 2 and 3).The external medications and its actions in this case of oligodendroglioma are discussed below.

Vayu performs the main function of cell division in the body. Whenever this function is altered, the division of cells become improper i.e.; either less or more. The treatment protocol starts with the sarvangaabhyanga with kottamchukaditaila and dhanvantaramtailam. Dalhana described the absorption of the medicine to different dhatus in the oleation of whole body (sarvangaabhyanga). Snigdaguna of the drugs is responsible for the snehana, kledana and vishyandana at cellular level of the body. According to Bhavaprakasha, guruguna in this taila will result in the vatahara, kaphakara, and pushtikara that will alleviate the morbid vatadosha and nourishes the body ${ }^{9}$. Seetaguna stabilizes the muscles and organs. Ghrita induces ketogenesis in body. Sukshmaguna helps to enter fine channels Choorna pinda sveda with kottamchukadi choorna was coming next in the protocol. It suggests the mode of action as an increase of body temperature due to passive heating substantially increases the cutaneous vascular conductance followed by a corresponding increase in systemic conductance. 
In any shodhana procedure doshautkleshana is necessary and is achieved by the abhyantara snehapana. In this case abhyantara snehapana is done with panchatikta guggulu ghrita from $25 \mathrm{ml}$ to $70 \mathrm{ml}$ on fourth day. Due to its sookshma and anabhisynadi properties it reaches the minute channels. Since it is tridoshahara, alleviates the morbid doshas along with control of vayu. Followed by virechana with avipattichoorna for eliminating the morbid doshas.

Nasya with anutailam and ksheerabala was then followed to get the shiroshodhana, since nose is considered as the gateway for the shiras ${ }^{10}$. Through the lipophilic action of the medicine it crosses the blood brain barrier and reaches the destination. This nasya is having a great action upon reducing the monotonous population of enlarged round cells in this case of oligodendroglioma.
Abhyanga and shirodhara with Brahmi taila and Kottamchukkadi taila. Shirodhara is coming under the murdini taila ${ }^{11}$. Shiras is having 37 marmas (vital points) among the whole 107 marmas in the body ${ }^{12}$. Shiras itself is the Sadyopranahara marma. Shirodhara treatment over Ajnya chakra.

Penial gland and Medulla oblongata in brain would stimulates Sahastrara chakra (the thousand petal lotus, the upper cerebral centre) which controls all chakras and give the preferred results.

Kayaseka with Dhanvantara taila, Kottamchukadi taila and Pinda taila was the last in treatment protocol for oligodendroglioma. This will pacify vata and vatakapha morbidity in the body. Oil which is hot when poured to the body to produce a mode of sweating.

Table 1. Treatment carried out for the patient

\begin{tabular}{|c|c|c|c|c|}
\hline Treatment & Ingredients & $\begin{array}{l}\text { Method of } \\
\text { Preparation }\end{array}$ & $\begin{array}{c}\text { Method of } \\
\text { Administration }\end{array}$ & $\begin{array}{l}\text { Duration of } \\
\text { Treatment }\end{array}$ \\
\hline $\begin{array}{c}\text { SarvāngaAbhyanga } \\
\text { with } \\
\text { KottamcukkādiTaila } \\
\text { and Dhānvantara } \\
\text { Taila }\end{array}$ & 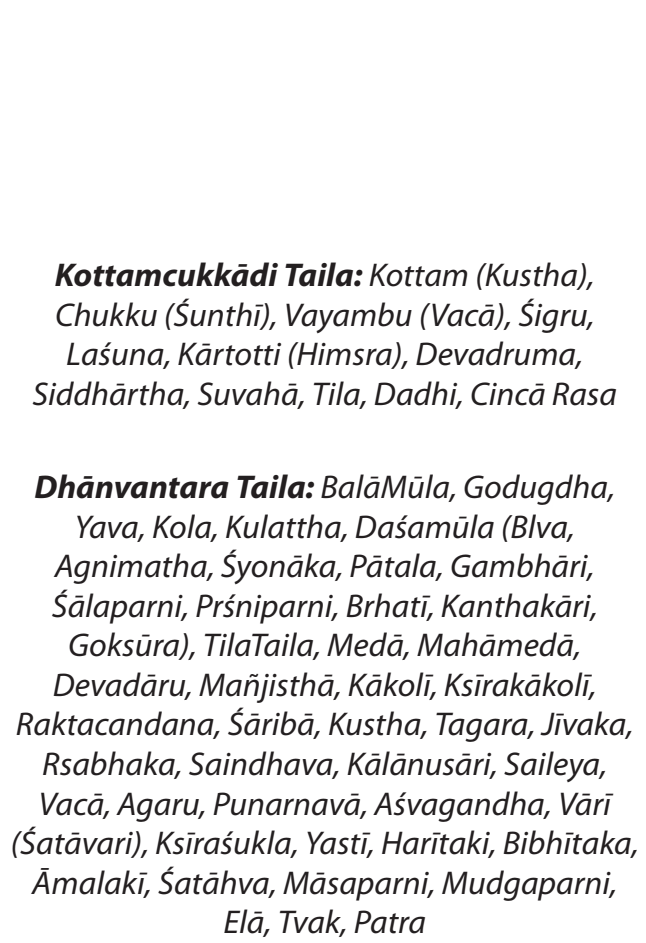 & $\begin{array}{l}\text { Kottamcukkädi } \\
\text { Taila: } \\
\text { Ingredients are } \\
\text { added to } 4 \text { parts } \\
\text { of Sneha and } \\
\text { cooked until } \\
\text { the kalka does } \\
\text { not stick to the } \\
\text { vessel. It is then } \\
\text { taken out and } \\
\text { strained. }\end{array}$ & $\begin{array}{l}\text { The patient lay } \\
\text { supine on the Droni. } \\
\text { Kottamcukkādi Taila } \\
\text { and Dhānvantara } \\
\text { Taila were mixed } \\
\text { together and } \\
\text { warmed. The } \\
\text { mixture was taken } \\
\text { and Abhyanga } \\
\text { (massage) was } \\
\text { done for } 45 \text { minutes } \\
\text { using the palms. }\end{array}$ & 3 days \\
\hline
\end{tabular}




\begin{tabular}{|c|c|c|c|c|}
\hline $\begin{array}{l}\text { CūrnaPindaSveda } \\
\text { with Kottamcukkādi } \\
\text { Cūrna }\end{array}$ & $\begin{array}{c}\text { Kottam (Kustha), } \\
\text { Chukku (Śunthī), Vayambu } \\
\text { (Vacā),Śigru, Laśuna, Kārtotti } \\
\text { (Himsra), Devadruma, } \\
\text { Siddhārtha, Suvahā, Tila, }\end{array}$ & $\begin{array}{l}\text { Preparation of the Cürna: } \\
\text { The ingredients are taken } \\
\text { equally, cleaned, and dried } \\
\text { properly. Each ingredient } \\
\text { is powdered and sieved } \\
\text { individually, and the } \\
\text { resultant fine powders are } \\
\text { mixed together. } \\
\text { Preparation of the Pottali } \\
\text { (boluses): Equal quantities } \\
\text { of the Cürna are placed } \\
\text { into a 4-piece cloth and } \\
\text { folded until they attain the } \\
\text { shape of a bolus. }\end{array}$ & $\begin{array}{l}\text { The patient lay } \\
\text { supine on the Droni. } \\
\text { The Pottalīs were } \\
\text { placed on a frying } \\
\text { pan and heated. } \\
\text { SarvāngaAbhyanga } \\
\text { (full-body massage) } \\
\text { was done with } \\
\text { Kottamcukkādi Taila } \\
\text { and Dhānvantara } \\
\text { Taila. The heated } \\
\text { boluses were applied } \\
\text { over the entire body } \\
\text { for } 45 \text { minutes. }\end{array}$ & 6 days \\
\hline $\begin{array}{c}\text { Snehapāna } \\
\text { with Pañcatikta } \\
\text { GugguluGhrta }\end{array}$ & $\begin{array}{c}\text { PañcatiktaGuggulu Ghrta } \\
\text { Nimba, Amrta, Vrsa, } \\
\text { PatolaNidigdhika, Pāhā, } \\
\text { Vidanga, Suradāru, } \\
\text { Gajopakulya, Dviksāra, } \\
\text { Nāgara, Niśā, Miśi, Cavya, } \\
\text { Kusthā, Tejovatī, Marica, } \\
\text { Vatsaka, Dīpyaka, Agni, Rohinī, } \\
\text { Āruskara, Vacā, Kanamūla, } \\
\text { Mañjistha, Ativisā, Visa, } \\
\text { Yavāni, ŚodhitaGuggulu }\end{array}$ & $\begin{array}{l}\text { Ingredients } 1-5 \text { are taken } \\
\text { in } 10 \text { Pala and boiled in } 1 \\
\text { Drona of water and reduced } \\
\text { to } 1 / 8 \text {. One Prastha of Ghrta } \\
\text { and a paste of ingredients } \\
6-29 \text { and } 5 \text { Pala of Guggulu } \\
\text { are added to the decoction } \\
\text { and ghee is prepared. }\end{array}$ & $\begin{array}{l}\text { Day 1: } 25 \mathrm{~mL} \\
\text { Day 2: } 40 \mathrm{~mL} \\
\text { Day 3: } 50 \mathrm{~mL} \\
\text { Day 4: } 70 \mathrm{~mL}\end{array}$ & 4 days \\
\hline $\begin{array}{c}\text { Virecana with } \\
\text { Avipattikara Yoga }\end{array}$ & $\begin{array}{c}\text { Avipattikara Yoga } \\
\text { Sunthī, Marica, Pippali, } \\
\text { Tvak, Patra, Ela, Ambhoja, } \\
\text { Krmighna, Āmalaki, Trvrt, } \\
\text { sugar }\end{array}$ & $\begin{array}{c}\text { Ingredients are taken } \\
\text { and powdered. An equal } \\
\text { quantity of sugar is added. }\end{array}$ & $\begin{array}{c}6 \mathrm{~g} \text { was given with } \\
\text { warm water to induce } \\
\text { Virecana. }\end{array}$ & 1 day \\
\hline $\begin{array}{c}\text { Nasya with Anutaila } \\
\text { and Ksirabala Taila }\end{array}$ & $\begin{array}{c}\text { Anutaila } \\
\text { Ksirrabala Taila }\end{array}$ & & & 7 days \\
\hline $\begin{array}{l}\text { Abhyanga and } \\
\text { Śirodhāra with } \\
\text { Brahmi Taila and } \\
\text { Kottamcukkādi Taila }\end{array}$ & $\begin{array}{c}\text { Brahmi Taila } \\
\text { Kottamcukkādi Taila }\end{array}$ & & & 7 days \\
\hline $\begin{array}{c}\text { Pizhiccil with } \\
\text { Dhānvantara Taila, } \\
\text { Kottamcukkādi Taila, } \\
\text { and Pinda Taila }\end{array}$ & $\begin{array}{c}\text { Pinda Taila } \\
\text { Madhucchistha, Mañjistha, } \\
\text { SarjarasaSāriva }\end{array}$ & & $\begin{array}{l}\text { The patient lay prone } \\
\text { on the Droni and the } \\
\text { lukewarm oil was } \\
\text { poured over the body } \\
\text { for } 45 \text { minutes. }\end{array}$ & 3 days \\
\hline
\end{tabular}


Table 2. Internal medicine administered

\begin{tabular}{|c|c|c|c|c|c|}
\hline Medicine & Ingredients & Dose & Anupāna & Duration & Manufacturer \\
\hline Kāñcanāra Guggulu & $\begin{array}{l}\text { Käñcanāratvak, Harìtakī, } \\
\text { Bibhïtaka, Āmalaki, Śunthī, } \\
\text { Marīca, Pippalī, Varuna, Ela, } \\
\text { Tvak, Patra, ŚodhitaGuggulu }\end{array}$ & $3 g$ & Warm water & $\begin{array}{c}10 / 07 / 2017 \\
- \\
01 / 08 / 2017\end{array}$ & $\begin{array}{l}\text { Aryavaidya } \\
\text { pharmacy }\end{array}$ \\
\hline Gudūcī Sattva & Amrta & & & $\begin{array}{c}10 / 07 / 2017 \\
- \\
01 / 08 / 2017\end{array}$ & \\
\hline Septillin & $\begin{array}{c}\text { Śodhita Guggulu, Śankha } \\
\text { Bhasma, Mahārāsnādi Kvātha, } \\
\text { Gudūci, Mañjistha, Āmalaki, } \\
\text { Śigru, Yastimadhu }\end{array}$ & 1 tablet & Warm water & $\begin{array}{c}10 / 07 / 2017 \\
- \\
01 / 08 / 2017\end{array}$ & Himalaya \\
\hline Aśvagandha capsule & Aśvagandha & $300 \mathrm{mg}$ & Warm water & $\begin{array}{c}10 / 07 / 2017 \\
- \\
01 / 08 / 2017\end{array}$ & Himalaya \\
\hline
\end{tabular}

Table 3. Timeline and procedure of treatment

\begin{tabular}{|c|c|c|}
\hline Treatment & Date & Procedure done \\
\hline $\begin{array}{c}\text { Kāñcanāra Guggulu Gudūcī } \\
\text { Sattva Septillin Aśvagandha } \\
\text { capsule }\end{array}$ & 10/07/2017 - 01/08/2017 & $\begin{array}{l}\text { Patient was admitted on July } 10^{\text {th }}, 2017 \text { and these internal } \\
\text { medicines were started and continued till discharge }\end{array}$ \\
\hline $\begin{array}{l}\text { Sarvānga Abhyanga with } \\
\text { Kottamcukkādi Taila and } \\
\text { Dhānvantara Taila Cūrna Pinda } \\
\text { Sveda with Kottamcukkādi } \\
\text { Cūrna }\end{array}$ & $11 / 07 / 2017-13 / 08 / 2017$ & $\begin{array}{l}\text { Patient was started with panchakarma therapies from } \\
\text { second day onwards. The mixture was taken and Abhyanga } \\
\text { (massage) was done for } 45 \text { minutes using the palms } \\
\text { followed by heated boluses were applied over the entire } \\
\text { body for } 45 \text { minutes. This was continued for } 3 \text { days. }\end{array}$ \\
\hline $\begin{array}{l}\text { Snehapāna with Pañcatikta } \\
\text { GugguluGhrta }\end{array}$ & 14/07/2017 - 17/08/2017 & $\begin{array}{l}\text { The patient was started with ghritapana for } 4 \text { days } \\
\qquad \begin{array}{l}\text { Day 1: } 25 \mathrm{~mL} \\
\text { Day 2: } 40 \mathrm{~mL} \\
\text { Day 3: } 50 \mathrm{~mL} \\
\text { Day 4: } 70 \mathrm{~mL}\end{array}\end{array}$ \\
\hline $\begin{array}{l}\text { Virecana with Avipattikara } \\
\text { Yoga }\end{array}$ & $18 / 07 / 2017$ & $\begin{array}{l}\text { The ghrita intake was stopped and the purgative drug was } \\
\text { given on the } 5^{\text {th }} \text { day after } 4 \text { of snehapana. }\end{array}$ \\
\hline $\begin{array}{l}\text { Nasya with Anutaila and } \\
\text { Ksīrabala Taila }\end{array}$ & 19/07/2017 - 25/08/2017 & $\begin{array}{l}\text { After the purgation the patient was started with nasal } \\
\text { medication for } 7 \text { days. }\end{array}$ \\
\hline $\begin{array}{l}\text { Abhyanga and Śirodhāra } \\
\text { with Brahmi Taila and } \\
\text { Kottamcukkādi Taila }\end{array}$ & 02/08/2017-04/08/2017 & $\begin{array}{l}\text { The patient was feeling better and starts the kayaseka for } \\
\text { the last } 3 \text { days. }\end{array}$ \\
\hline $\begin{array}{l}\text { Kayaseka with Dhānvantara } \\
\text { Taila, Kottamcukkādi Taila, and } \\
\text { Pinda Taila }\end{array}$ & $02 / 08 / 2017-04 / 08 / 2017$ & $\begin{array}{l}\text { The patient was feeling better and starts the kayaseka for } \\
\text { the last } 3 \text { days. }\end{array}$ \\
\hline
\end{tabular}




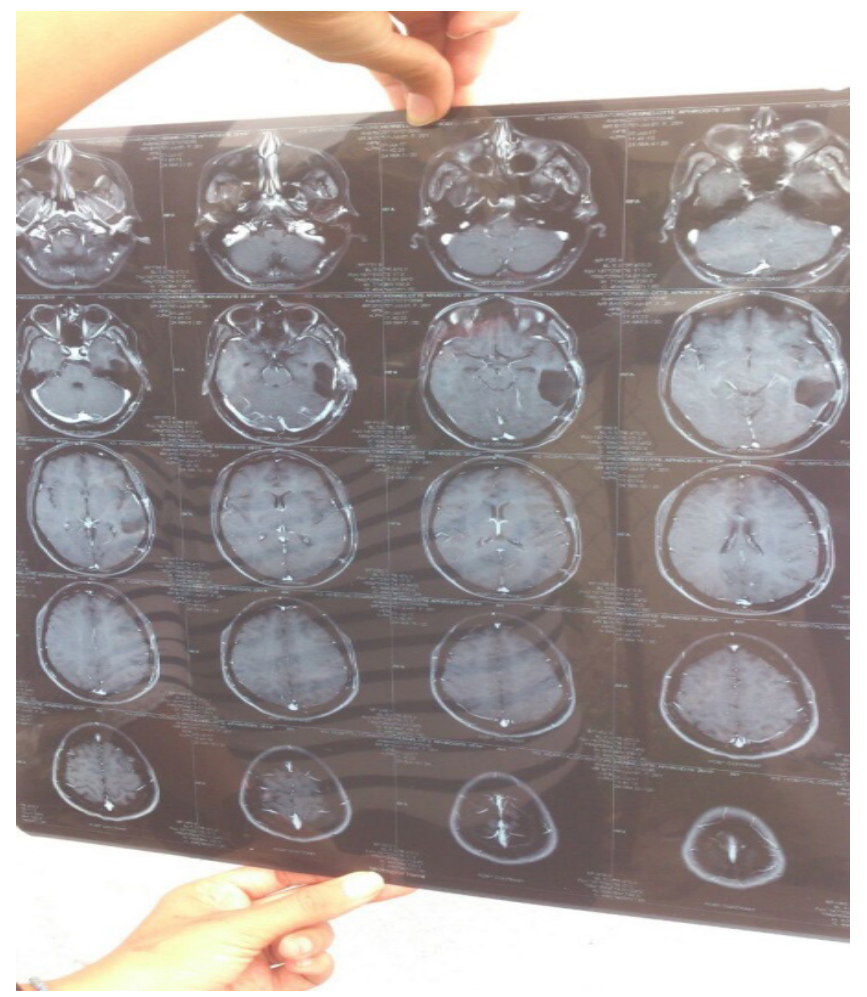

A

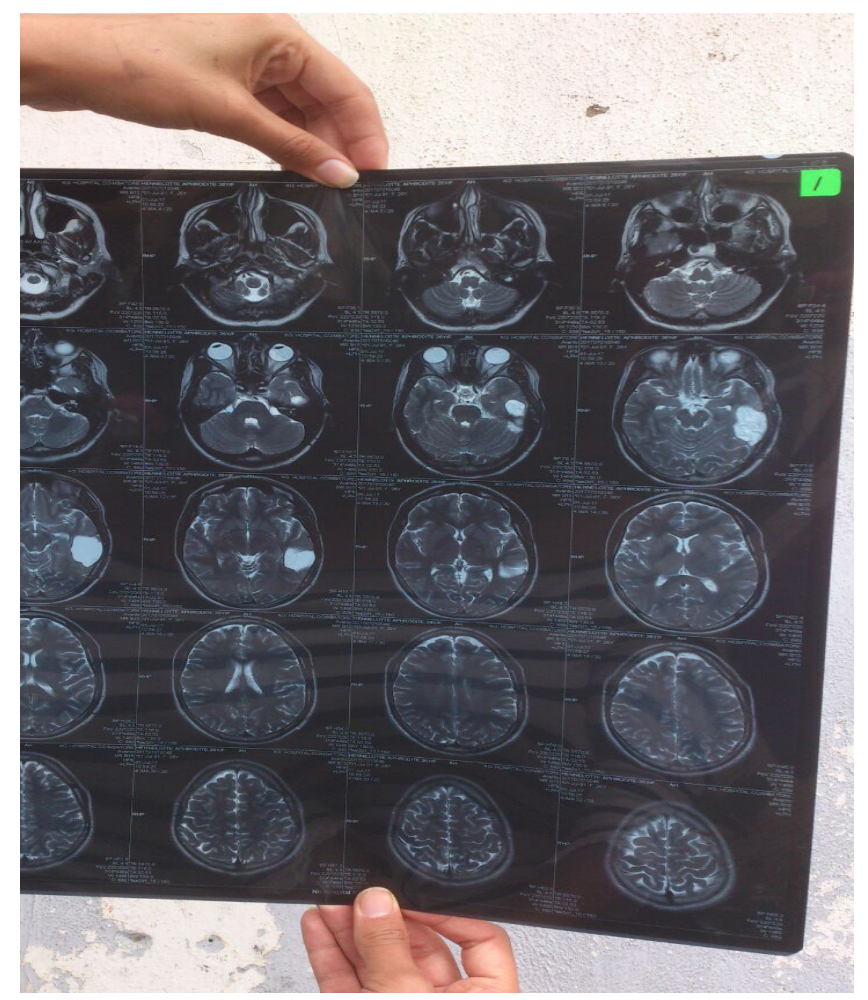

B

Figure 1. MRI scans before (A) and after (B) treatment

\section{Conclusion}

The present study shows the management of arbudachikitsa which was designed and it was followed in the oligodendroglioma patient. The arbuda spectrum of conditions mentioned by Acharya Sushruta can be taken as a general guideline to understand the path physiology of oligodendroglioma. Highly significant result was obtained in treating the Grade II oligodendroglioma. Area of hyper intensity and subtle swelling left temporal without diffusion restriction or staining, hardly changed except possibly subtle decrease in swelling between $24 / 8$ and $13 / 8$. On the first scan already cystic / softened parties dated resistant damage or still under tumor. Major deviations of the left temporal lobe, without staining or diffusion restriction with signs of tissue loss. Normalization of the deviations from glandulaparotis. Enlarged pituitary gland, even visible on the external images, but initially less pronounced, dated hypophysitis. Space occupying lesion in the left temporal cerebral part suggesting the Grade II oligodendroglioma. The MRI results after treatment clearly suggest the significant reduction of the Grade II oligodendroglioma which was suggested for the resection and chemotherapy (Figure 1). Based on this data it can be concluded that this Ayurvedic management is highly significant in the case of Grade II oligodendroglioma. So we can use this Ayurveda treatment for the management of oligodendroglioma. But it is only a single case. Multiple clinical trials should be conducted to establish this treatment as general treatment for the oligodendroglioma.

\section{Patient Consent}

The patent has provided written consent for publication.

\section{Acknowledgement}

Thank Nilgiris Ayurvedic Treatment centre Pvt Ltd for their help in preparing this case report. Also grateful to the authors/editors/publishers of all those articles, journals and books from where the literature for this article has been reviewed and discussed.

\section{References}

1. Oligodendroglioma [Internet]. 2021 [cited 8 February 2021]. Available from: https://en.wikipedia.org/wiki/ Oligodendroglioma 
2. Nistēśvar K, Vidyanath R. Sahasrayogam, Taila Prakarana - 12, Varanasi: Chowkhamba Sanskrit Series Office; 2006. p. 67-70.

3. Murty KRS. Astanga Hridaya Sārīrasthana 2, Chaukamba Krishnadas Academy Varanasi; 2006. p. 22-34.

4. Murty KRS. Astanga Hridaya Cikitsa Sthāna. Chaukamba Krishnadas Academy Varanasi; 2006. p. 21/58-61.

5. Nistēśvar K, Vidyanath R. Sahasrayogam, Churna Prakarana, Varanasi: Chowkhamba Sanskrit Series Office; 2006. p. 56-7.

6. Murty KRS. Astanga Hridaya Sutra stana 20, Chaukamba Krishnadas Academy Varanasi; 2006. p. 34-7.

7. Murty KRS. Astanga Hridaya Chikitsa stana 22/5861, Chaukamba Krishnadas Academy Varanasi; 2006. p. 58-61. https://doi.org/10.1256/wea.179.05
8. Gupta AK. Vidyalankar, Ashtanga Hridaya, Uttara tantra, 29/16-17, 4th edition, publication-Chaukamba Sanskrit series office, Varanasi.

9. Mishra BB, Vidyatini Hindi commentary. Bhav prakash, 2005, 8/44, publication Chaukambabharti academy.

10. Gupta AK. Vidyalankar, Ashtanga Hridaya, Sūtrasthāna, 20, 4th edition, publication- Chaukamba Sanskrit series office, Varanasi. p. 15-19.

11. Gupta AK, Vidyalankar, Ashtanga Hridaya, Sūtrasthāna, 23, 4th edition, publication-Chaukamba Sanskrit series office, Varanasi. p. 11-13.

12. Gupta AK. Vidyalankar, Ashtanga Hridaya, Saārīrasthana, 4, 4th edition, publication- Chaukamba Sanskrit series office, Varanasi. p. 6-7 